\title{
Brogitaros and the Pessinus-Affair Some Considerations on the Galatian Background of Cicero's Lampoon against Clodius in 56 BC (Harusp. Resp. 27-29)
}

\author{
Altay COŞKUN*
}

\section{The Romanness of Our Perspective on Ancient Pessinus}

The sanctuary of Kybele Agdistis in Pessinus is considered to be one of the most famous of ancient Anatolia, if not the ancient world at large. Most recent research is, however, increasingly skeptical of its alleged Phrygian past, or at least of any renown that the cult place might have enjoyed beyond the narrow confines of the Gallos Valley so early in time. Scholars are thus ever more inclined to take seriously the lateness of the material, literary and epigraphic evidence. Some of them now believe that the foundation of the so-called temple state may well have happened as late as the $3^{\text {rd }}$ century. I have suggested elsewhere that we should put more trust in Strabo's brief account on Pessinus, because he seems to be hitting the nail when he claims: "Famous has the sanctuary been made by the Romans, when they sent for the statue of the throned goddess (aphidryma) from there, following the oracles of the Sibyl, just as in the case of the statue of Asklepios at Epidauros." ${ }^{\prime \prime}$ The reference to the aphidry$m a$ is certainly anachronistic, for we know that the Roman ambassadors brought home an aniconic meteorite (baitylos) in 205/4 BC. ${ }^{2}$ This concession notwithstanding, the main allegation is still consistent with the rest of Strabo's report, namely that the architectural splendor of Pessinus was owed to the Attalid kings, and that the humble remains of a great Phrygian past have to be sought outside the Gallos Valley on the banks of the Sangarios River. ${ }^{3}$

* Assoc. Prof. Dr. Altay COŞKUN, University of Waterloo, Department of Classical Studies, ML 228, Waterloo ON, N2L 3G1 (acoskun@uwaterloo.ca).

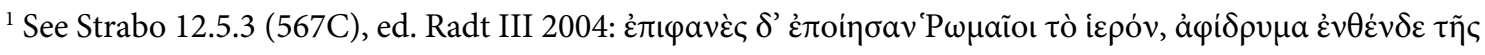

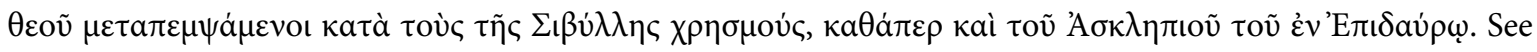
Coşkun 2018a on the early history of the cult site in the $3^{\text {rd }}$ century BC and idem ca. 2019 for the $3^{\text {rd }}$ to $1^{\text {st }}$ centuries BC.

2 The main narrative is Livy 29.10.4-29.11.8 for the quest in 205 BC and 29.14.5-14 for the return of the embassy in 204 BC. On the baitylos in particular, see Roller 1999, 256.

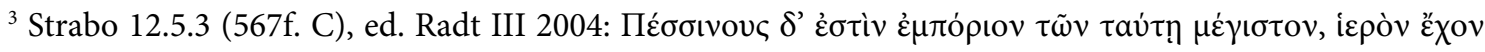

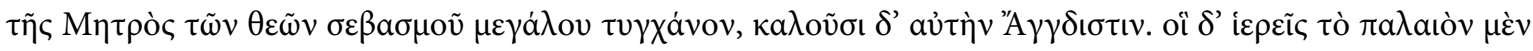

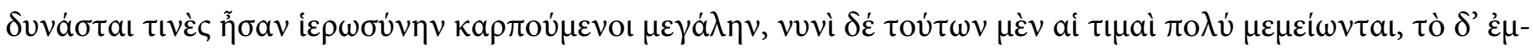

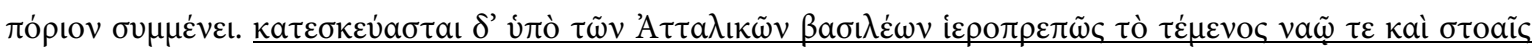

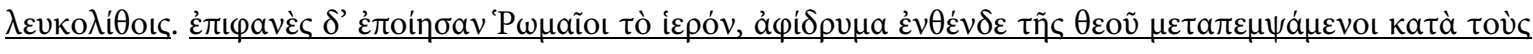

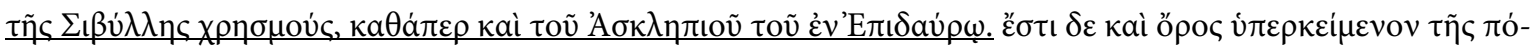

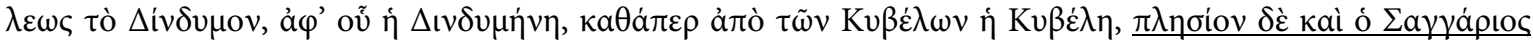

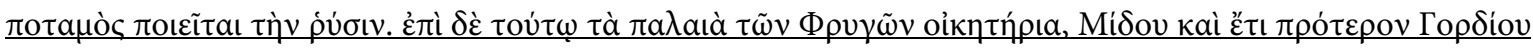

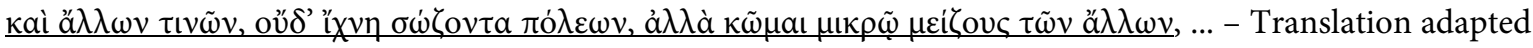
from the Loeb ed. 
This assessment also appears to be in line with what the archaeological evidence known to this day is suggesting. ${ }^{4}$

Strabo's claim seems to be further confirmed by the extent and nature of our literary sources. If we exclude references to a mythical past that connect the life or - more importantly - the death of Attis with the cult place, the extant historiographical texts exclusively relate to events that involved the Romans: This started with the abovementioned Roman quest for the Mother Goddess in 205/4 BC, goes on with the brief encounter between Manlius Vulso and the messengers of Attis and Battakes during the campaign against the Galatians in $189 \mathrm{BC},{ }^{5}$ and includes the visit of the priest king Battakes in Rome in 102 BC. ${ }^{6}$ For the $1^{\text {st }}$ century BC, we have some passing notes of Romans who travelled to or through Pessinus: Marius fulfilled a solemn vow to the Mother Goddess at her Pessinuntine sanctuary in 98/97 BC; ${ }^{7}$ on his way back from the Mithradatic War, the younger Cato was expected to pass through Pessinus where the Tolistobogian tetrarch Deiotaros was hoping to win his political support through splendid gifts (ca. $66 \mathrm{BC}){ }^{8}$ during his proconsulship in Cilicia (51/50 BC), Cicero encountered the Galatian nobleman Adiatorix on his way to Pessinus, where he was to meet with representatives of Marcus Caelius for business purposes. ${ }^{9}$

The focus of the present paper will be on Cicero's polemical rendering of the most famous incident of the history of Pessinus through the $1^{\text {st }}$ century $\mathrm{BC}$, a violent conflict over the control of the sanctuary. Cicero's testimonies have previously been adduced to briefly add two events to the lacunose annals of central Anatolia: first the expulsion of the ruling priest by the Trokmian Brogitaros in 58 $\mathrm{BC}$ and then the reversal brought about by the Tolistobogian Deiotaros in 56 BC. Otherwise, discussions have concentrated on the inner-Roman political strife among the last generation of the Roman Republic. ${ }^{10}$ A closer analysis of Cicero's rhetoric will allow us to uncover some overlooked aspects of Pessinuntine and Galatian history.

\footnotetext{
${ }^{4}$ The most recent comprehensive surveys of the archaeology of the Gallos Valley do not yet draw such a radical conclusion, but admit to the scarcity of physical evidence for the pre-Attalid period: Tsetskhladze 2009 and 2013; Verlinde 2010; Claerhout and Devreker 2010. However, in combination with the lack of literary, epigraphic and numismatic evidence, a number of scholars have argued for the low significance of the sanctuary prior to 205 BC: see Gruen 1990; Roller 1999, esp. 257; Bowden 2012; Coşkun 2018a (with further bibliography). - The now foundational work on the history of Pessinus (Tsetskhladze 2018) appeared too late to be considered here.

${ }^{5}$ Polyb. 21.37.4-7; cf. Livy 38.18.7.

${ }^{6}$ Diod. 36.13 and Plut. Mar. 17.5f.

${ }^{7}$ Plut. Mar. 31.1; cf. Cic. Harusp. 28 (quoted below, n. 25) and Val. Max. 1.1.1.

${ }^{8}$ Plut. Cat. min. 12.2f.; 15.1-3. This reference is often regarded as an indication of the rule of Deiotaros over the place (e.g., Ruge 1937, 1107; Virgilio 1981, 124 n. 335; Devreker 1984, 17; Mitchell I 1993, 34; Strobel 2000, 659), but economic activity at the foremost emporion in central Anatolia does not imply rule. Also see below, section IV.

${ }^{9}$ Cic. Epist. ad fam. 2.12.2 = 95 ShB.

${ }^{10}$ For the political, legal and interpersonal aspects, see the references below, n. 14; for the financial implications, see below, n. 13 .
} 


\section{Clodius and the Conflict over Pessinus - a Sketch of the Roman Perspective}

Cicero is our only witness for the violent conflict surrounding the right of appointing the Pessinuntine priest. He refers to the incidents several times, though for the only reason that the responsible Roman legislator happened to be his personal archenemy, the notorious tribune of the plebs of 58 BC, Publius Clodius. When he unexpectedly rose to power, Clodius did what Roman senators tended to do: they sought to consolidate their material and personal power base and to weaken the resources of their opponents. In this case, he was happy to promote the Trokmian Galatian Brogitaros at the cost of the Tolistobogian Galatian Deiotaros, all the more so since this came with a substantial payment in support of his political agenda.

Clodius' previous relation with Brogitaros cannot be ascertained due to the lack of any positive evidence. We only have a few vague references to his travels to Asia Minor prior to 58 BC: they might well have been connected with the issue. ${ }^{11}$ But in a passing remark, Cicero mentions a contract that had been set up between Clodius' secretary and "the ambassadors of Brogitaros", a detail that would once more suggest that the Trokmian had initiated the Pessinuntine issue when Clodius was probably in Italy. ${ }^{12}$ What mattered most for the tribune is that, in Asia Minor, Deiotaros was the staunchest supporter of Pompey, who, in turn, was Clodius' main political opponent. ${ }^{13}$ Deiotaros was an even more attractive target since he was also friends with the family of Cicero, with whom Clodius had a private bill to settle, too. Immediately upon assuming his position as tribune of the plebs in December $59 \mathrm{BC}$, he agitated against Cicero and soon caused him to depart into exile. In his wrath, Clodius went even further: he confiscated and destroyed his enemy's home on the Palatine Hill, and consecrated the ground to ensure the loss for Cicero would be irreversible. ${ }^{14}$

Not much later in his turbulent tribuneship, Clodius had the assembly of the Roman people grant the royal title to Brogitaros, this way making him an equal of Deiotaros, the only Galatian whom Pompey had conceded the diadem in 65/64 BC. The same bill transferred the rights over Pessinus to Brogitaros as well. Deiotaros abided with the new terms, as long as Pompey and his friends such as Cicero were in weak positions. He even allowed Brogitaros to expel the ruling priest and to replace

${ }^{11}$ Clodius is first attested in the East as a legatus of Lucullus in the Third Mithradatic War from 69 to 66 BC, though nothing in the sources connects him to Pessinus or Galatia (Plut. Luc. 34; Cass. Dio 36,17,2f.). In 59 BC, he may have travelled to Armenia as a legatus of the Roman Senate (Cic. Att. 2,4,2; 2,7,2f. [24; 27 ShB]), though it has been doubted whether the travel plans came into effect (Rawson 1973/91, 118-122). We thus do not know if negotiations about the transfer of the power over Pessinus took place in Asia Minor or in Rome. Also note that Clodius was seeking a libera legatio to the East in $55 \mathrm{BC}$, which seemed to involve Byzantion and Brogitaros (Cic. Q.fr. 2,8,2 [13 SB]); what the specific matters were, we are not told, but Cicero comments: plena res nummorum. It has been suggested that Clodius wanted to exact debts from Brogitaros (Shatzman 1975, 326), who likely stopped payments after having lost Pessinus in 56 BC (Hoben 1969, 77; Shackleton Bailey 1980, 189).

${ }^{12}$ Cic. Dom. 129: si tuus scriptor in illo incendio civitatis non syngraphas cum Byzantiis exsulibus et cum legatis Brogitari faceret.

${ }^{13}$ Lenaghan 1969 remains somewhat undecided: financial implications are prevalent in his discussion (pp. 133; 138; 139; also see below, n. 19), while harming Pompey through Deiotaros is also admitted (p. 134), though this contradicts Clodius' expectation to receive payment from Deiotaros as well (p. 138).

${ }^{14}$ On the details of Cicero's exile and his return, which form the context of the speech, see Lenaghan 1969, 14-28; also Gelzer 1969, 135-159 (153-155 on Harusp.) and Stockton 1971, 176-214 (p. 197 on Harusp.), who do not even mention the case of Pessinus. 
him with a man of his own liking. ${ }^{15}$ But, in $56 \mathrm{BC}$, Clodius was finally silenced by Caesar, and Pompey was back in control of Roman politics. Deiotaros did not hesitate to take back Pessinus, probably returning the previous priest at the expense of Brogitaros' candidate. ${ }^{16}$

Cicero addresses the conflict in three of his speeches held within about a year after his return from exile (58-57 and 57-56 BC respectively). In all these instances, Cicero is fiercely attacking the Roman rival who had made him suffer so much, renouncing no opportunity to discredit his opponent as a politician or to denigrate his character. ${ }^{17}$ We should therefore be cautious not to make Cicero's personal vendetta our own, and we ought to refrain from inadvertently adopting his moralizing judgments about Clodius and Brogitaros. ${ }^{18}$

The case, as presented here, appears as a mere extension of Ciceronian strives. Rarely have scholars tried to give more credit to the Roman tribune. ${ }^{19}$ Most importantly, Elizabeth Rawson has pointed out that the gens Clodia had broader interests in the East, and in addition they could boast a historical connection with the cult of the Mother Goddess: a certain Quinta Claudia is said to have overcome the obstacles to bringing home to Rome the baitylos in 204 BC. Her prominent role is also attested

15 The view that Brogitaros became the Kybele priest of Pessinus himself is wide-spread (thus Klebs 1897, 887; Rawson 1973/91, 121; Sherwin-White 1984, 270; Spickermann 1997, 789), but mistaken; for a discussion, see Lenaghan 1969, 133, who, however, remains undecided. While Cicero's wording is open to misunderstanding, Brogitaros' responsibility for the pollution of the cult does not require him to have become the priest himself. Neither should we conclude with Claerhout and Devreker 2008, 32 that the temple and its estate became the direct possession of Brogitaros, as if cult and priesthood had been discontinued altogether. On the biographies of the two Galatians, see Hoben 1969; Sullivan 1990; Mitchell I 1993; Syme 1995; Coşkun 2005; ca. 2018b; APR s.vv. Brogitaros and Deiotaros.

${ }^{16}$ Admittedly, the inner-Roman political context was more complex; and if Lenaghan 1969, 22-31 should be right to date the speech into the first half of May 56 BC (cf. Marinone 2004, 119 for more recent bibliography), Deiotaros would have taken action before the conference of Luca in April 56 BC. But a time in summer 56 BC remains a possibility; Gelzer 1969, 174-176 goes as far as autumn, though without a detailed argument.

${ }^{17}$ Cic. Harusp. 28f. (56 BC, quoted below). Also see Cic. Sest. 56 (56 BC): lege tribunicia Matris Magnae Pessinuntius ille sacerdos expulsus et spoliatus sacerdotio est, fanumque sanctissimarum atque antiquissimarum religionum venditum pecunia grandi Brogitaro, impuro homini atque indigno illa religione, praesertim cum eam sibi ille non colendi, sed violandi causa adpetisset; appellati reges a populo, qui id numquam ne a senatu quidem postulassent. And cf. the allusions in Cic. Dom. 60 (57 BC): cum post meum discessum omnium locupletium fortunas, omnium provinciarum fructus, tetrarcharum ac regum bona spe atque avaritia devorasses; 129 (quoted above, n. 11). One may add the allusions in Cic. Harusp. 58f.; Mil. 76 (52 BC) omitto socios exteras nationes reges tetrarchas.

18 Thus, however, e.g., Thomas 1984, 1504; Syme 1995, 132.

${ }^{19}$ E.g., Sullivan 1990, 164 suggests that the decisions in favor of Brogitaros were meant to stabilize Galatia after the one-sided support for Deiotaros had caused uproar among Galatian nobles; Hoben 1969, 75f. is even more specific in this regard: "Die trokmischen Garnisonstruppen mussten vielmehr die Schwäche des Deiotarus sogar im eigenen Stammesgebiet verdeutlichen.”. More typical is the view of Sherwin-White 1984, 270: the whole conflict was part of Clodius' machinations. Somewhat more substantiated is Shatzman 1975, 324-326, who contextualizes the affair by detailing Clodius' excessive spending practices and constant need for money. On the financial implications, also see Mitchell I 1993, 34; Spickermann 1997, 789, and above, n. 13. 
by Livy. ${ }^{20}$ Rawson may be right that there was more to Clodius' involvement with Pessinus than the extant sources allow us to see today. Yet we have to admit that we cannot substantiate any direct relation with either the Pessinuntine sanctuary proper or a Galatian tribe that predates Clodius' initiative favoring Brogitaros in $58 \mathrm{BC}^{21}$

And yet the tradition of the semi-legendary ancestress of Clodius is of some interest. While Cicero avoids mentioning her in the immediate narrative of the Pessinus affair in his De haruspicum responsis (28f.), he does refer to her in the preceding section (27). The main purpose of the highly polemical speech was to rebut Clodius' objections against Cicero resuming possession of his previously confiscated urban estate. Roman authorities had closely examined the case and confirmed that the consecration in $58 \mathrm{BC}$ had been invalid (Harusp. 9-16), but Clodius responded by producing an opaque soothsayer, hoping that this might reverse the decision of the senate (18-21). Cicero's whole speech is thus designed to prove the righteousness of his own claim (namely that there were no valid religious obstacles to resuming his property) and to discredit Clodius' authority in any religious matters, if not to ridicule him wholesale. The Pessinus affair (28f.) is only one among several other 'misdeeds' treated in this context. As such, it is preceded by a reference to the aforementioned Claudia (27): ${ }^{22}$

“... when Italy was wearied by the Punic war and harassed by Hannibal, our ancestors imported that sacred cult from Phrygia, and established it at Rome, where it was received by that man who was adjudged to be the most virtuous of all the Roman people, Publius Scipio Nasica, and by the woman who was considered the chastest of the matrons, Quinta Claudia; her oldfashioned strictness your sister is considered to have imitated in a wonderful manner. Did, then, neither your ancestors, connected as they were with these religious ceremonies, nor the priesthood itself, by which all these religious observances were established, nor the curule aedileship, which above all things is accustomed to uphold this worship, influence you to abstain from polluting those most holy games with every sort of crime, and polluting them with infamy, and involving them in guilt?"

The reference to the chaste ancestress is part of yet another accusation against Clodius (24-27), namely to have drawn too generously on slaves for the organization of the Megalesia in his capacity as aedilis curulis earlier in the same year (4-9 April 56 BC). This festival commemorated the arrival

${ }^{20}$ Liv. 29.14.12: matronae primores ciuitatis, inter quas unius Claudiae Quintae insigne est nomen, accepere; cui dubia, ut traditur, antea fama clariorem ad posteros tam religioso ministerio pudicitiam fecit. For more ancient references to Claudia, see Lenaghan 1969, 131; Dyck 2013, 114.

${ }^{21}$ Rawson 1973/91, 114; 121; 1977/91, 240. Also see above, n. 11, for a broader interest of Clodius in the East. And see below on Claudia.

22 Cic. Harusp. 27: ... defessa Italia Punico bello atque <ab> Hannibale vexata, sacra ista nostri maiores adscita ex Phrygia Romae conlocarunt; quae vir is accepit qui est optimus populi Romani iudicatus, P. Scipio, femina autem quae matronarum castissima putabatur, Q. Claudia, cuius priscam illam severitatem \{sacrificii\} mirifice tua soror existimatur imitata. Nihil te igitur neque maiores tui coniuncti cum his religionibus, neque sacerdotium ipsum, quo est haec tota religio constituta, neque curulis aedilitas, quae maxime hanc tueri religionem solet, permovit quo minus castissimos ludos omni flagitio pollueres, dedecore maculares, scelere obligares? Latin text adapted from thelatinlibrary.com; English translation adapted from C. D. Yonge 1891, accessed through the Perseus Database. Differently, Yonge translates the neuter plural sacra ista as "that sacred image and those sacred rites", but see above, n. 2, on the baitylos. He also maintains sacrificii and thus translates "the old-fashioned strictness of whose sacrifice". 
of the Meter Megale in the form of the Pessinuntine baitylos. Quinta Claudia is invoked by Cicero, only to be contrasted with the promiscuous (or allegedly also incestuous) sister of Clodius. One brief ironic allusion suffices to bring back to mind how Cicero had slandered her in his defense speech For Marcus Caelius. It was a rare coincidence that the trial against Caelius was held during the very days of the Megalesia of $56 \mathrm{BC}$. The chaste ancestress was also evoked then as a contrast foil to Clodia, whom Cicero presented as a rejected mistress seeking revenge, though, somewhat surprisingly, no explicit connection to the cult of the Mother Goddess was drawn at the time. ${ }^{23}$ Thus a great opportunity for a pun was lost - at least if Cicero was already aware that the tradition of Quinta Claudia's chastity was linked with her reception of the baitylos. The first explicit connection that we know of was made only a few months later in Cicero's attack on Clodius' tribuneship in the above-quoted section of the De haruspicum responsis. It is at least a possibility that the tradition was not so old after all, perhaps even fabricated by Clodius in the context of his legislation as tribune, details of which Cicero became aware only gradually after his return. ${ }^{24}$

Be this as it may, it is quite possible that Clodius hoped to enhance the legitimacy of his involvement in Pessinuntine matters with reference to Quinta Clodia. Further plausible is the assumption that Cicero let himself be inspired by the motivations Clodius had put forward in $58 \mathrm{BC}$, if only to turn the latter's rhetoric against him. Admitting this, we need to confess that, in both the Pro Caelio and the De haruspicum responsis, Cicero has failed to address (and distort) any proper connections to Pessinus (or the Galatians) that Clodius might have wanted to draw on while proposing his Pessinuntine bill in $58 \mathrm{BC}$.

\section{Cicero's Rendering of the Pessinus Affair}

Let us now have a closer look at the longest extant source on the matter, which is the section following immediately after the above-quoted lines in the De haruspicum responsis (28f.): ${ }^{25}$

\footnotetext{
${ }^{23}$ Cic. Cael. 34: Q. illa Claudia, aemulam domesticae laudis in gloria muliebri esse admonebat, non uirgo illa Vestalis Claudia quae patrem complexa triumphantem ab inimico tribuno plebei de curru detrahi passa non est? All remaining evidence for Claudia (see above, n. 20) is later.

${ }^{24}$ Or might it be Cicero himself who spun this part of the legend?

${ }^{25}$ Cic. Harusp. 28f.: Sed quid ego id admiror? qui accepta pecunia Pessinuntem ipsum, sedem domiciliumque Matris Deorum, vastaris, et Brogitaro Gallograeco, impuro homini ac nefario, cuius legati te tribuno dividere in aede Castoris tuis operis nummos solebant, totum illum locum fanumque vendideris, sacerdotem ab ipsis aris pulvinaribusque detraxeris, omnia illa quae vetustas, quae Persae, quae Syri, quae reges omnes qui Europam Asiamque tenuerunt semper summa religione coluerunt, perverteris; quae denique nostri maiores tam sancta duxerunt ut, cum refertam urbem atque Italiam fanorum haberemus, tamen nostri imperatores maximis et periculosissimis bellis huic deae vota facerent, eaque in ipso Pessinunte ad illam ipsam principem aram et in illo loco fanoque persolverent. / quod cum Deiotarus religione sua castissime tueretur, quem unum habemus in orbe terrarum fidelissimum huic imperio atque amantissimum nostri nominis, Brogitaro, ut ante dixi, addictum pecunia tradidisti. atque hunc tamen Deiotarum saepe a senatu regali nomine dignum existimatum, clarissimorum imperatorum testimoniis ornatum, tu etiam regem appellari cum Brogitaro iubes. sed alter est rex iudicio senatus per nos, pecunia Brogitarus per te appellatus ... alterum putabo regem, si habuerit, unde tibi solvat, quod ei per syngrapham credidisti. nam, cum multa regia sunt in Deiotaro, tum illa maxime, quod tibi nummum nullum dedit, quod eam partem legis tuae, quae congruebat cum iudicio senatus, ut ipse rex esset, non repudiavit, quod Pessinuntem per scelus a te violatum et sacerdote sacrisque spoliatum reciperavit, ut in pristina religione servaret, quod caerimonias ab omni vetustate acceptas a Brogitaro pollui non sinit, mavultque generum suum munere tuo
} 
"But why do I wonder? when, having taken a bribe, you ravaged Pessinus itself, the habitation and home of the Mother of the Gods, and sold to Brogitaros - a fellow half Gaul, half Greek, a profligate and impious man, whose agents, while you were tribune, used to pay you the money for your share of the work in the temple of Castor - the whole of that place and the temple; when you dragged the priest from the very altar and cushion of the goddess; when you perverted those omens which all antiquity, which Persians, and Syrians, and all kings who have ever reigned in Europe and Asia have always venerated with the greatest piety; which, last of all, our own ancestors considered so sacred, that though we had the city and all Italy crowded with temples, still our generals in our most important and most perilous wars used to offer their vows to this goddess, and to pay them in Pessinus itself, at that identical principal altar and on that spot and in that temple.

And when Deiotaros was protecting this temple in the most holy manner with the deepest feelings of religion - Deiotaros, of all allies the most faithful to this empire and the most devoted to our name - you gave it to Brogitaros as I have said before, having sold it to him for a sum of money. And yet you order this Deiotaros who has been repeatedly declared by the senate worthy of the name of king and adorned with the testimony of many most illustrious generals in his favor, to be styled king together with Brogitaros. But one of them has been called king by the decision of the senate through my instrumentality. Brogitaros has been called king by you for money. And I will think him a king, indeed, if he has any means of paying you what you have trusted him with on his note of hand. For there are many royal qualities in Deiotaros; this was the most royal of all, that he gave you no money; that he did not repudiate that portion of your law which agreed with the decision of the senate, namely that he was a king; that he recovered Pessinus, which had been impiously violated by you and stripped of its priest and its sacrifices, in order to maintain it in its accustomed religion; that he does not suffer the ceremonies which have been received as handed down from the most remote antiquity, to be polluted by Brogitaros; and that he prefers to let his son-in-law be deprived of your liberality, rather than to allow that temple to lose the ancient reverence due to its religious character."

The machinations of Clodius and Brogitaros are thus viewed as violent and sacrilegious, as resulting from bribery and greed. Since Cicero had suffered so much from Clodius, no one will blame him for his partisanship and exaggerations. And yet we should try to explore the roles of Deiotaros and Brogitaros a bit further, to elicit from this speech some hitherto overlooked information on the history of Pessinus.

\section{Deiotaros' Claim to Pessinus}

For the most part, Deiotaros' legitimacy is based on his "religiosity" and on his "outstanding loyalty" to Rome. Cicero points out that Deiotaros' royal title had been decreed by the senate with the endorsement of Cicero (est rex iudicio senatus per nos). ${ }^{26}$ Not even Clodius could question Deiotaros' leading position in principle; he even considered it useful to explicitly confirm Deiotaros' royalty in the very bill that was designed to raise Brogitaros to kingship as well (tu etiam regem appellari cum

quam illud fanum antiquitate religionis carere. Latin text adapted from thelatinlibrary.com; English translation adapted from C. D. Yonge 1891, accessed through the Perseus Database; on the difficulties regarding the transmitted pecunia Brogitarus per te appellatus, see the discussion of Lenaghan 1969, 138.

${ }^{26}$ This does not relate to Deiotaros' control of Pessinus, see below. 
Brogitaro iubes). ${ }^{27}$ Soon thereafter, the highest authority of the senate in acknowledging the position of Deiotaros is emphasized, again (eam partem legis tuae, quae congruebat cum iudicio senatus, ut ipse rex esset, non repudiavit). This is coupled with an amazingly euphemistic expression for the fact that Deiotaros did not even wait for a new legal basis to reverse the previous plebiscitum: he simply resorted to taking the sanctuary back, and this probably by violence (quod Pessinuntem per scelus a te violatum et sacerdote sacrisque spoliatum reciperavit, ut in pristina religione servaret). The rhetoric focusses on delegitimizing the bill of $58 \mathrm{BC}$ as 'criminal' (per scelus), avoiding any mention of the fact that the Roman assembly had agreed to it. Accordingly, the entire blame is put on Clodius' greed (pecunia ... pecunia ... per syngrapham).

Here we see the rhetorician at his best: the world appears in black and white, and one may firmly believe to know who enjoyed legitimacy and who lacked it. Barely anyone has therefore asked the question what specifically justified Deiotaros' claim over Pessinus. ${ }^{28}$ The average Roman citizen would somehow have taken for granted that Deiotaros, as the only remaining king in central Anatolia, would have enjoyed this privilege of the neighboring sanctuary. It is commonly accepted today that, despite the close-to autonomous position that leading priests of major sanctuaries enjoyed, they were still appointed or deposed by the kings who controlled the surrounding territories. ${ }^{29}$ As we can see in the De haruspicum responsis, this kind of power was quite effectively styled as a moral or religious duty, at least by those sympathizing with the king. Modern scholars have, in turn, been misguided by the general assumption that Pessinus had been part of the Tolistobogian territory for up to two centuries - an assumption that is quite fragile. As has been argued elsewhere in more detail, not only is the above-quoted section from Cicero the first piece of evidence for the control of the sanctuary by a Tolistobogian ruler, but the sources for the $3^{\text {rd }}$ and $2^{\text {nd }}$ centuries imply either rivaling or complementary authority of the Attalids and the Galatian Tektosages. ${ }^{30}$

Thanks to Cicero, we can now add some further indirect proof that the Tolistobogians did not have any close links to Pessinus until the second-last generation of the Hellenistic age. The orator cannot do better than pretending that Brogitaros was polluting the "holy rites that have come down from

${ }^{27}$ Unconvincingly, Lenaghan 1969, 138 assumes that Clodius was also expecting payments from Deiotaros, which were, however, refused. Neither is it correct to say that Deiotaros owed his title to Clodius (thus, however, Mitchell I 1993, 34). See below, with n. 32.

${ }^{28}$ Stähelin 1907/73, 89 explicitly denies a legal title to both Brogitaros and Deiotaros; cf. Hoben 1969, 77: "Doch Deiotarus fehlte offenbar ebenso jeder Rechtsanspruch auf Pessinus, den Cicero in seinen Ausfällen gegen Clodius und Brogitarus bei der lobenden Erwähnung des Königs sicher nicht übergangen hatte.”

${ }^{29}$ Olshausen 1987, 87; 196; Boffo 2007. Cf. Devreker 1984, 17f. who claims that Brogitaros' authority over Pessinus was based on his royalty.

${ }^{30}$ For the attribution of Pessinus to a Tolistobogian territory, see, e.g., Hoben 1969, 56f.; 75f.; Mitchell I 1993, 34. More generally, it is described as a part of Galatian territory by Strubbe 2005, 1. Other scholars claim independence prior to the $1^{\text {st }}$ century BC, whether this had to be defended with force (Ruge 1937, 1106f.) or was respected by the Tolistobogii (Strobel 2000, 659). Particularly frequent is the inconsistent view that Pessinus was part of a Galatian or Tolistobogian territory, but independent nevertheless (Lenaghan 1969, 131f.; 133; 139; Devreker 1984, 14f.). More balanced is Boffo 1985, 34: “"Stato templare» per antonomasia, nei suoi caratteri strutturali e nella sua funzione rispetto all'autorità reale con cui venne a contatto, prima che in una forma di onorevole dipendenza, fu quello con centro a Pessinunte, collocato - di volta in volta, e insieme - fra, ed entro, le regioni frigia e galata." For a systematic discussion that weighs the evidence for Attalid and Galatian control, see Coşkun 2016 and ca. 2019. 
most ancient times" (caerimonias ab omni vetustate acceptas). But, notably, Deiotaros could not base his claim on a right that his father or any other ancestor might have enjoyed previously. We only learn that Deiotaros had effectively been in control before Brogitaros took over (cum Deiotarus religione sua castissime tueretur). Cicero's silence has some further remarkable implications: Deiotaros' claim over Pessinus is not justified as a gift of Pompey (as we know the Pontic territories were) ${ }^{31}$ it is not justified either as a grant of the senate, which, as we have just seen, the royal title was (and which was also the case with his Kingdom of Armenia Minor); ${ }^{32}$ his control over the sanctuary is neither explained as an award by the Roman people (that is by a plebiscitum or lex, such as the so-called lex Vatinia of 59 BC, which sanctioned all of Pompey's arrangements in the east en bloc). ${ }^{33}$

Accordingly, Clodius and Brogitaros had not infringed on any certified or inherited rights that Deiotaros enjoyed, but rather responded to a fait accompli. Their sacrilege melts down to expelling a priest of uncertain legitimacy, this way causing some disruption to the functioning of the venerated sanctuary. It appears that the need for appointing a successor to a deceased Attis priest arose after Pompey had left Asia Minor in $62 \mathrm{BC}$, and Deiotaros - then being the only king in the nearby of Pessinus and the most powerful individual of Asia Minor - seized the opportunity. Being the mightiest neighbor of Pessinus to the north, and having the Tektosages (whose tetrarch was another of Deiotaros' sonsin-law) as a buffer to the east, potential claims by the rival Brogitaros, who resided with his Trokmians further to the east within the bend of the Halys River, could easily be ignored.

\section{Brogitaros' Claim to Pessinus}

Even if we accept that Deiotaros had no effective legal claim to Pessinus but only usurped power over it, we may still believe that most Roman politicians, thus also the citizens of the voting assemblies, would have been inclined to grant the control over the sanctuary to him. After all, he was the most appreciated among their allies, highly deserving of many rewards for his services in the Mithradatic Wars. In contrast, his rival Brogitaros was barely known to the Romans, as is also implied in his being

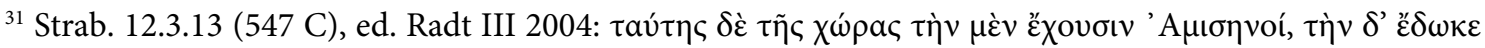

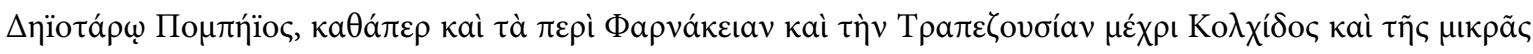

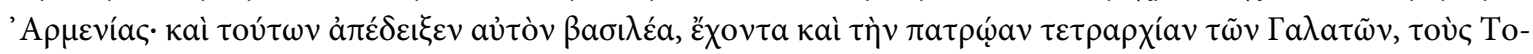

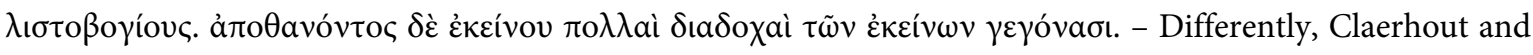
Devreker 2008, 32 assume that Deiotaros' rule over Pessinus was established under the proconsulship of Pompey; however, the expected meeting with Cato (see above, n. 8) does not prove this.

${ }^{32}$ Cic. Div. 2.79: is cum ei Trocmorum tetrarchian eripuisset et adseculae suo Pergameno nescio cui dedisset eidemque detraxisset Armeniam a senatu datam; Phil. 2.94: computarat pecuniam, in eius tetrarchia unum ex Graecis comitibus suis conlocarat, Armeniam abstulerat a senatu datam; [Caes.] Bell. Alex. 67.1: Deiotarus ... sine dubio autem rex Armeniae minoris ab senatu appellatus. Lenaghan 1969, 137 discusses, whether Deiotaros owed his royal title to Pompey or the senate. Misled is the claim of Stark 2007, 85 that Deiotaros had been given Pessinus by the senate; likewise erroneous is the assumption that Clodius took control of it.

${ }^{33}$ This was in fact a plebiscitum promulgated by the tribune Vatinius in cooperation with the consul Caesar: Vell. 2.44.2 hoc consilium sequendi (sc. to join the so-called 'First Triumvirate') Pompeius causam habuerat, ut tandem acta in transmarinis proviniciis, quibus, ut praediximus, multi obtrectabant, per Caesarem confirmaren-

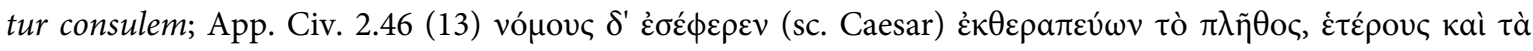

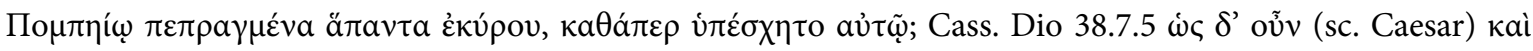

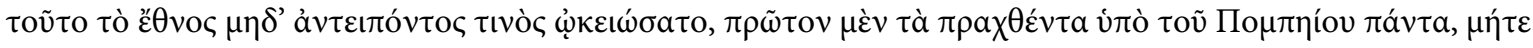

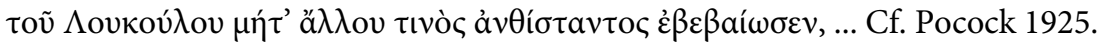


disqualified as Gallograecus. Those few senators who were aware of the latter's career would have remembered his former close relation with Mithradates Eupator. His stained past would thus barely have incited sympathies in Rome. Should we still assume that the support of Clodius was enough to transfer the right over Pessinus to the Trokmian dynast? I rather see a high plausibility that Brogitaros himself - or possibly one of his predecessors as the rulers of the Trokmian tribe - had formerly held the privilege of appointing the Pessinuntine priest. There is, admittedly, no positive evidence for my hypothesis, but at least there is both Roman and Galatian context that would support such a view.

One possibility is that Mithradates V Euergetes had granted this privilege to the Trokmians after the Romans had passed on Greater Phrygia to him around 129 BC. Alternatively, the Romans might have rewarded the Trokmians directly with Pessinus for serving in the war against Aristonikos (133-129 BC) - their support for Rome is likely, even though not attested. Either way, this would have been a welcome source of income for the poorest of the Galatian tribes, since they were still roaming around in the dry steppes of the Axylon south of the territories of the Tolistobogians and Tektosages. The military occupation of the Galatian territories by Mithradates VI Eupator around 107/2 BC provided yet another possible opportunity for such an arrangement. ${ }^{34} \mathrm{I}$ have recently ventured the suggestion that it was the same Eupator who granted the Trokmians the territory within the Halys Bend around Tavion, ${ }^{35}$ a gift that in all likelihood postdated the grant of Pessinus. While those reconstructions remain speculative to a certain degree, it is well known that the Trokmians developed the closest ties to Eupator among all the Galatians. Most famously, Adobogiona, the sister of the tetrarch Brogitaros, was his mistress for a while, probably when he had his court in Pergamon during the First Mithradatic War (89/88-84 BC). Although she soon married Menodotos, one of the leading citizens of Pergamon, her son was called Mithradates in honor of the king. ${ }^{36}$

\section{Epilogue}

At the end of this chapter, it should be emphasized once more that the main arguments put forward here are hypothetical and lack the authority of positive evidence. It is the silence about Anatolian matters that is typical, interrupted only sporadically when interactions with the Attalids, Mithradatids or Romans are referred to. Yet I hope to have shown that the silence in the case of the prehistory of the Pessinus affair is a highly qualified one that allows us at least to venture some suggestions about the Galatian background of the conflict.

Were it not for the strong dedication of Deiotaros to Rome and its leading generals, we would know far less about Galatian History in the $1^{\text {st }}$ century BC, and probably would not even have notice of a conflict about the Pessinuntine priesthood under Brogitaros. Deiotaros is attested as the leader of the

\footnotetext{
${ }^{34}$ On the occupation of Galatia, see Justin 37.4.6, with Ballesteros Pastor 1996, 56-60; Coşkun 2015, 170; ca. 2018 b. If indeed the Romans offered the ornamenta regalia to Battakes in 102 BC, as Virgilio 1981, 123 suggests, Galatian supremacy would have been excluded or formally rejected; but this is not expressed in our sources, see above, n. 6.

${ }^{35}$ See above, section 4 with n. 38.

${ }^{36}$ Heinen 1994; Ballesteros Pastor 2008; Coşkun 2018b. - It is less likely that Pessinus was gifted to Brogitaros during the First Mithradatic War, first since their territory was then clearly disconnected from the Gallos Valley, and second because we would likely have traces of complaints by those who had previously enjoyed the privilege.
} 
resistance against Eupator as of $86 \mathrm{BC}$, whereas the Trokmians seem to have remained loyal to Eupator for another few years. Ultimately, they changed sides, too, and a marriage between Deiotaros' daughter and Brogitaros sealed the new alliance sometime around $80 \mathrm{BC}$. It was also thanks to the vigor of Deiotaros that Eupator failed to occupy Galatia and Phrygia during the Third Mithradatic War (73-63 BC). Towards the end of the war, Pompey raised Deiotaros to the position of a rex amicus populi Romani, bestowing on him the rule over major parts of the dissolved Pontic Kingdom. ${ }^{37}$ It seems to have been this position of strength that encouraged him to seize control of the small but wealthy Gallos Valley as well. He hoped he could quietly appoint a new Attis priest loyal to him without raising the concerns of the Romans. At any rate, it seems unlikely that Tolistobogian control of Pessinus was assumed prior to $62 \mathrm{BC}$. Otherwise it would most likely have been acknowledged by Pompey, thus also by the lex Vatinia, a legal title that Cicero would not have failed to mention.

Brogitaros, in turn, would barely have dared extorting a privilege from his overbearing father-in-law, had he not had a strong claim to Pessinus. The political reversals in Rome in $58 \mathrm{BC}$ allowed him to prevail at least temporarily, but, in the long run, Pompey was more influential than Clodius and Deiotaros more powerful than his Trokmian rival. The first Tolistobogian take-over of Pessinus thus falls into the years 62-58 BC, before their rule became permanent in $56 \mathrm{BC}$. Those years, then, form the starting point that led to a gradual amalgamation of the Tolistobogians and the Phrygians of the Gallos Valley, which would come into effect only later under Augustus, when Pessinus became the urban centre of the westernmost Galatian tribe. ${ }^{38}$

\section{Bibliography}

Ballesteros Pastor 1996

Ballesteros Pastor 2008

Boffo 1985

Boffo 2007

Bowden 2012

Claerhout - Devreker 2008

Coşkun, APR

Coşkun 2005
L. Ballesteros Pastor, Mithrídates Eupátor, rey del Ponto, Granada 1996.

L. Ballesteros Pastor, Mithradates (VII) of Pergamon, in: A. Coşkun (ed.), APR.

L. Boffo, I re ellenistici e i centri religiosi dell'Asia Minore, Florence 1985.

L. Boffo, I centri religiosi d'Asia Minore all'epoca della conquista romana, in: G. Urso (ed.), Tra Oriente e Occidente. Indigeni, Greci e Romani in Asia minore. Atti del convegno internazionale, Cividale del Friuli, 28-30 settembre 2006, Rome 2007, 105-128.

H. Bowden, Rome, Pessinous, and Battakes: Religious Encounters with the East, in: Ch. Smith - M. Yarrow (eds.), Imperialism, Cultural Politics, and Polybius, Oxford 2012.

I. Claerhout - J. Devreker, Pessinous: An Archaeological Guide, İstanbul 2008.

A. Coşkun (ed.), Amici Populi Romani, Trier 2007-2008 and Waterloo $2010 \mathrm{ff}$. Online: http://www.altaycoskun.com/apr.

A. Coşkun, Amicitiae und politische Ambitionen im Kontext der causa Deiotariana, in: A. Coşkun (ed.), Roms auswärtige Freunde in

\footnotetext{
${ }^{37}$ On Deiotaros' political biography, see above, n. 15.

${ }^{38}$ On this development, see, e.g., Coşkun 2009.
} 
Coşkun 2009

Coşkun 2011

Coşkun 2013

Coşkun 2014

Coşkun 2015

Coşkun, 2016

Coșkun, 2018a

Coşkun, ca. 2018b

Coşkun, ca. 2019

Devreker 1984

Dyck 2013 der späten Republik und im frühen Prinzipat, Göttingen 2005, 127154.

A. Coşkun, Der Ankyraner Kaiserkult und die Transformation galatischer und phrygisch-galatischer Identitäten in Zentralanatolien im Spiegel der Münzquellen, in: A. Coşkun - H. Heinen - S. Pfeiffer (eds.), Identität und Zugehörigkeit im Osten der griechisch-römischen Welt. Aspekte ihrer Repräsentation in Städten, Provinzen und Reichen, Frankfurt am Main 2009, 173-210.

A. Coşkun, Galatians and Seleucids: a Century of Conflict and Cooperation, in: K. Erickson - G. Ramsey (eds.), Seleucid Dissolution: Fragmentation and Transformation of Empire (Exeter, July 2008), Wiesbaden 2011, 85-106.

A. Coşkun, Von Anatolia bis Inscriptions of Ankara: Zwanzig Jahre Forschungen zum antiken Galatien (1993-2012), Anatolica 39, 2013, 69-95.

A. Coşkun, Latène-Artefakte im hellenistischen Kleinasien: ein problematisches Kriterium für die Bestimmung der ethnischen Identität(en) der Galater, Istanbuler Mitteilungen 64, 2014, 129-162.

A. Coşkun, Die Tetrarchie als hellenistisch-römisches Herrschaftsinstrument. Mit einer Untersuchung der Titulatur der Dynasten von Ituräa, in: E. Baltrusch - J. Wilker (eds.), Amici - Socii - Clientes. Abhängige Herrschaft im Imperium Romanum, Berlin 2015, 161197.

A. Coşkun, Attalos I and the Conquest of Pessinus. I. Pessinus 1 Reconsidered, Philia 2, 2016, 53-62.

A. Coşkun, The Temple State of Kybele in Phrygian and Early Hellenistic Pessinus: a Phantom?, in: G. R. Tsetskhladze (ed.), Pessinus and Its Regional Setting, vol. 1, Leuven 2018, 205-243.

A. Coşkun, Mithridates Eupator: Retter, Hegemon, Feind und Opfer der Galater, forthcoming in: D. Braund - A. Dan (eds.), Mithridates and the Pontic Kingdom (Collection Varia Anatolica), Paris, ca. 2018.

A. Coşkun, The 'Temple State' of Phrygian Pessinus in the Context of Seleukid, Attalid, Galatian and Roman Hegemonial Politics (3rd1st Centuries BC), forthcoming in: G. Tsetskhladze (ed.), The Phrygian Lands over Time (from Prehistory to the Middle of the 1st Millennium AD). Proceedings of the International Conference, Anadolu University, (Eskişehir, 2nd-8th November, 2015), ca. 2019.

J. Devreker, L'histoire de Pessinonte, in: J. Devreker - M. Waelkens (eds.), Les Fouilles de la Rijksuniversiteit te Gent a Pessinonte, 19671973. Hommage à Pieter Lambrechts, Bruges 1984, vol. I, 13-37.

A. R. Dyck, Cicero: Pro Marco Caelio, Cambridge-New York 2013. 
Gruen 1990

Hoben 1969

Klebs 1897

Lenaghan 1969

Marinone 2004

Mitchell 1993

Olshausen 1987

Pocock 1925

Rawson 1973/91

Rawson 1977/91

Roller 1999

Ruge 1937

Shackleton Bailey 1980

Shatzman 1975

Sherwin-White 1984

Spickermann 1997

Stähelin 1907/73

Stark 2007

Stockton 1971

Strobel 2000

Strubbe 2005
E. Gruen, The Advent of the Magna Mater, in: E. Gruen (ed.), Studies in Greek Culture and Roman Policy, Leiden 1990, 5-33.

W. Hoben, Untersuchungen zur Stellung kleinasiatischer Dynasten in den Machtkämpfen der ausgehenden römischen Republik, Diss. Mainz 1969.

E. Klebs, Brogitarus, RE 3,1, 1897, 887.

J. O. Lenaghan, A Commentary on Cicero's Oration de Haruspicum Responso, The Hague 1969.

N. Marinone, Cronologia Ciceroniana, ${ }^{1}$ Rome 1997; ${ }^{2}$ Bologna 2004.

S. Mitchell, Anatolia. Land, Men, and Gods in Asia Minor I: The Celts and the Impact of Roman Rule; II: The Rise of the Church, Oxford 1993.

E. Olshausen, Der König und die Priester. Die Mithradatiden im Kampf um die Anerkennung ihrer Herrschaft in Pontos, in E. Olshausen - H. Sonnabend (eds.), Stuttgarter Kolloquium zur Historischen Geographie des Altertums I, Bonn 1987, 187-212.

L. G. Pocock, Lex de actis Cn. Pompei confirmandis: lex Iulia or lex Vatinia?, CQ 19, 1925, 16-21.

E. Rawson, The Eastern Clientelae of Clodius and the Claudii, Historia 22, 1973, 219-239 = E. Rawson, Roman Culture and Society, Oxford 1991, 102-124.

E. Rawson, More on the Clientelae of the Patrician Claudii, Historia 26, 1977, 340-357 = E. Rawson, Roman Culture and Society, Oxford 1991, 227-244.

L. E. Roller, In Search for the Mother: The Cult of Anatolian Cybele, Berkeley 1999.

Ruge, Pessinus, RE 19.1, 1937, 1104-1113.

D. R. Shackleton Bailey, Cicero: Epistulae ad Quintum fratrem et M. Brutum, Cambridge 1980.

I. Shatzman, Senatorial Wealth and Roman Politics, Brussels 1975.

A. N. Sherwin-White, Roman Foreign Policy in the East (168 B.C. to A.D. 1), London 1984.

W. Spickermann, Brogitarus, DNP 2, 1997, 789.

F. Stähelin, Geschichte der kleinasiatischen Galater, Osnabrück 1897, ${ }^{2} 1907$, repr. 1973.

I. Stark, Kybele als keltische Göttin: Zur Aufnahme der Kybele von Pessinus als Mater Magna unter die römischen Staatsgötter 205/204 v. Chr., Klio 89.1, 2007, 67-117.

D. Stockton, Cicero. A Political Biography, Oxford 1971.

K. Strobel, 'Pessinus', DNP 9, 2000, 658-660.

J. Strubbe, The Inscriptions of Pessinous (IK 66), Bonn 2005. 
Sullivan 1990

Syme 1995

Tsetskhladze 2009

Tsetskhladze 2013

Tsetskhladze 2018

Verlinde 2010

Virgilio 1981
R. D. Sullivan, Near Eastern Royalty and Rome, 100-30 B.C., Toronto 1990.

R. Syme, Anatolica. Studies in Strabo, ed. by A. Birley, Oxford 1995.

G. R. Tsetskhladze, Notes on Phrygian Pessinus, in: H. Sağlamtimur (ed.), Studies in Honour of Altan Çilingiroğlu. A Life Dedicated to Urartu on the Shores of the Upper Sea, İstanbul 2009, 703-717.

G. R. Tsetskhladze, Pessinus in Central Anatolia: New Investigations, in: G. Labarre - H. Bru (eds.), L'Anatolie des peuples, cités et cultures (IIe millénaire av. J.-C. - Ve siècle ap. J.-C.). Vol. II: Approches locales et regionals, Besançon 2013, 41-80.

G. R. Tsetskhladze (ed.), Pessinus and Its Regional Setting, vol. 1, Leuven 2018.

A. Verlinde, Monumental Architecture in Hellenistic and JulioClaudian Pessinus, BABESCH 85, 2010, 111-139.

B. Virgilio, Il «Templo Stato» di Pessinunte fra Pergamo e Roma nel II-I secólo A.C., Pisa 1981.

\section{Brogitaros ve Pessinus Meselesi}

Cicero'nun İ. Ö. 56'daki Clodius hicvinin Galatia Arkaplanı Hakkında Bazı Düşünceler (Harusp. Resp. 27-29)

Özet

Pessinus'un Hellenistik Dönem tarihine ilişkin mevcut tüm edebi kaynaklar Roma müdahalesini içermektedir. Çoğunlukla bu kaynaklar Roma politik ve ekonomik çıkarlarına odaklanan ve bizzat tapınakla ilgili bilgiyi, çarpıtmasa bile, önemli ölçüde sınırlayan Roma bakış açısıyla güçlü bir biçimde şekillenmiştir. Buna çarpıcı bir örnek Cicero'nun De haruspicum responsis eserinin 27.-29. bölümlerinde Publius Clodius'a karşı yaptığı hararetli bir tartışmadan bir kesittir. Bu, Pessinus'un kontrolünü Tolistobog Deiotaros yerine Trokmi Brogitaros'a bahşeden yasa hakkındaki temel kaynağımızdır. Cicero'nun kullandığı retorik, modern araştırmacıları, bu olayı, gerçekten de olması gerektiği gibi, Roma Cumhuriyet Dönemi çekişmeleri içinde ele almak konusunda cesaretlendirmiş ama aynı zamanda bu çatışmanın arkasında spesifik olarak Galatia'nın müdahil oluşunu daha iyi anlamaya yarayacak girişimlerin de hevesini kırmıştır. Buna rağmen, Cicero'nun polemiklerini, ama özellikle de söylemediği şeylerin yansımasının ustaca bir analizi, bize Attalos Krallı̆̆ı'nın İ. Ö. 133/129'da sona erişinin ardından Pessinus'un az bilinen tarihine ilişkin bazı mantıklı hipotezler ortaya koymamıza imkân verecektir. Böyle yaparak, Tolistobog'ların Pessinus'a olan ilgisinin oldukça geç olduğuna ve bu emporion'un Tolistobog'ların kent merkezi oluşuna uzanan gelişim sürecinin İ. Ö. 60'lı yıllar civarında başlamış olabileceğine dair görüşlere dair başka argümanlar elde edebiliriz.

Anahtar Sözcükler: Pessinus, Brogitaros, Deiotaros, Cicero, P. Clodius Pulcher, Pompeius, Mithradates VI Eupator, Tolistobogn Galatları, Trokmi Galatları, Tapınak devletleri, Hellenistik Krallık. 


\section{Brogitaros and the Pessinus-Affair \\ Some Considerations on the Galatian Background of Cicero's Lampoon against Clodius in 56 BC \\ (Harusp. Resp. 27-29) \\ Abstract}

All of our extant literary sources on the history of Pessinus in the Hellenistic age involve Roman agency. For the most part, they are strongly shaped by a specifically Roman perspective that focuses on Roman political or economic interests, and in a way that significantly limits, if not distorts, the information on the sanctuary itself. A telling example is a section from Cicero's fervent lampoon against Publius Clodius, De haruspicum responsis 27-29. This is our main source for the law that granted the control of Pessinus to the Trokmian Brogitaros at the cost of the Tolistobogian Deiotaros. Cicero's rhetoric has encouraged modern scholars to contextualize this incident within Roman Republican strives - which is indeed pertinent -, but, at the same time, discouraged attempts to better understand specifically Galatian agency behind the conflict. However, a subtle analysis of Ciceronian polemics, especially a reflection on what Cicero does not say, will allow us to put forward some plausible hypotheses about the otherwise poorly attested history of Pessinus after the end of the Attalid Kingdom in 133/129 BC. By doing so, we shall gain further arguments for the view that Tolistobogian interest in Pessinus was very late, and that the development of this emporion to the urban center of the Tolistobogians may well have started as late as around $60 \mathrm{BC}$.

Keywords: Pessinus, Brogitaros, Deiotaros, Cicero, P. Clodius Pulcher, Pompey, Mithradates VI Eupator, Tolistobogian Galatians, Trokmian Galatians, Temple States, Hellenistic Kingship. 